DOI 10.18524/2304-1587.2018.2(33).147031

UDC 342.9:339.543

Ye. O. Katashynskyi

student

Odessa I. I. Mechnikov National University,

The Department of Administrative and Commercial Law

Frantsuzskiy Boulevard, 24/26, Odessa, 65058, Ukraine

\title{
SOME ASPECTS OF LEGAL REGULATION OF THE USE OF VEHICLES THAT ARE REGISTERED IN THE EUROPEAN UNION ("EUROCARS") 1
}

The article considers the legal regimes for the use of vehicles registered outside the territory of Ukraine («Eurocar»), identifies the main and optional features of such cars. Also, the actual definition of the category of «Eurocar» is proposed. Within the framework of the work, the judicial practice is analyzed in the sphere of bringing the person to responsibility for non-payment of customs payments within the term established by law, as well as possible options for solving the issue.

Key words: foreign vehicles, customs rules, «Eurocars».

Problem statement. Every day on Ukrainian roads the number of vehicles registered in foreign countries is increasing. The most common are cars registered in Poland and Lithuania, which are popularly known as «Eurocars» . Typically, such vehicles are driven by Ukrainian citizens, and the cars themselves are in the territory of our state on the basis of transit or temporary importation. A major factor in this problem is the large number of such cars. We made the request for public information to the State Fiscal Service of Ukraine about the number of such cars in the territory of Ukraine. Thus, from 1 January 2014 to 13 July 2018, 1921608 cars were imported. As of July 13, 2018, there were 362525 «Eurocars» on the territory of Ukraine. That is, there are currently more than $1 / 3$ million cars which were imported to Ukraine without paying customs payment. Meanwhile legitimate owners of such vehicles are residents of other states.

Analysis of research and publications. In accordance with the fact, that the problem of legal regulation of the use of «Eurocars» is rather new, this issue is reflected only in separate articles on various websites ${ }^{2}$.

\footnotetext{
${ }^{1}$ Scientific supervisor - O. V. Haran, Doctor of Law, Associate Professor, Professor of the Department of Administrative and Economic Law of the Odessa I. I. Mechnikov National University

${ }^{2}$ See more:

1) http://www.visnuk.com.ua/uk/publication/100007205-vvezennya-avtomobiliv-zinozemnoyu-reyestratsiyeyu;

2) https://www.autocentre.ua/blogs/hto-maye-pravo-yizditi-na-nerozmitnenomu-avto-vukrayini-372272.html;

3) http://shoppingpl.com/uk/post/177-avtomobil-na-inozemnykh-nomerakh-yak-zakonnojizdyty-v-ukrajini;

4) https://auto.24tv.ua/yak_lehalno_yizdyty_na_polskykh_nomerakh_v_ukraini_n4421;

5) https://www.bbc.com/ukrainian/features-41190797.
} 
Paper purpose of the article is to distinguish the features of the category of «Eurocars», to provide its own interpretation of this term, as well as to search for solutions to the problem of «Eurocars».

Paper main body. In our opinion, in order to understand the legal nature of «Eurocars» and to develop a certain model of solution of this problem, it is necessary to understand what is it in general.

It is known, any term can be interpreted by means of its features. We suppose the signs of «Eurocars» should be divided into main and facultative.

The main features of the «Eurocars» are: 1) vehicle registered in compliance with the law in one of the member states of the European Union; 2) imported into the territory of Ukraine without payment of the necessary customs payments; 3) stays in the territory of Ukraine in custom procedure of transit or temporary importation

In this case, the use of the category "vehicle» but not for example «a car» is explained by the fact that this term more clearly reflects the essence of the concept of "Eurocars», including in itself both cars and motorcycles that can also be registered in a foreign the state and stay in Ukraine in conformity with the custom procedure of transit or temporary importation.

The distinction of the sign of the origin of the vehicle from the EU member state is reflected in the term - the "Eurocars», in which the Euro prefix itself focuses on the European origin of the vehicle.

One of the main features of any "Eurocars» is that such a vehicle was brought into the territory of Ukraine without paying the required customs payments. However, this feature can not be considered without the fourth main feature of «Eurocar» - stay in Ukraine on the grounds of transit or temporary importation. This position is confirmed by the fact that the legal regime of transit and temporary importation provides the opportunity to use the vehicle within the legally allowed time frame without paying customs duties.

These legal regimes are the most widespread and used today. Their legal regulation is carried out by the Customs Code of Ukraine (hereinafter - the CC of Ukraine) [1]. In accordance with Part 1 of Article 103 of the CC of Ukraine Temporary import means a customs procedure whereby foreign goods, means of transport for commercial use are brought into the customs territory of Ukraine for specific purposes with full or partial relief from customs duties and without their being subject to non-tariff regulation of foreign economic activity and are intended for re-export prior to the expiration of the established period without having undergone any change except normal depreciation due the use made of them.

Part 1 and 2 of Article 380 of the CC of Ukraine stipulate that temporary importation of means of transport for private use by non-resident citizens into the customs territory of Ukraine shall be permitted for a period of up to one year (but this period may be increased by 60 days in cases stipulated by law). The mandatory condition for such importation is the registration of these vehicles in the authorized bodies of foreign states. This shall be confirmed by the relevant document. Passenger transport vehicles, which are temporarily imported into the customs territory of Ukraine by non-resident citizens, are not subject to written declaration. The passage of such vehicles through the customs border of Ukraine is carried out without application of the guarantee measures provided for in Section X of the CC of Ukraine. In this case, if the importation of vehicles is carried out by a resident citizen, he undertakes to 
provide a written commitment on their re-exportation after payment of all necessary customs payments.

It is obligatory to emphasize the position of Part 4 of Article 380 of the CC of Ukraine, according to which temporarily imported vehicles for personal use can be used in the customs territory of Ukraine exclusively by citizens who imported the specified vehicles in Ukraine for their personal needs. This means that the car, which is in the customs procedure of temporary importation, can not be alienated to a third person.

Legal regulation of the custom procedure of transit is reflected in the CC of Ukraine. Thus, Part 1 of Article $90 \mathrm{CC}$ of Ukraine defines transit as a customs procedure whereby goods and/or means of transport for commercial use are moved under customs supervision between two revenue and duties authorities of Ukraine or within the operation area of separate revenue and duties authority without any use of those goods, without collecting any customs charges and without their being subject to non-tariff regulation of foreign economic activity.

The term of transit transportation for motor transport is determined by paragraph 1 part 1 of Article 95 of CC of Ukraine and can not exceed 10 days (in the case of moving in the area of one custom office -5 days);

The requirements of Part 1 of Article 381 of the CC of Ukraine establish that citizens are allowed to import vehicles for personal use without their written declaration and making a monetary deposit in the amount of customs duties, if such vehicles are permanently registered with the relevant registration authorities of a foreign state, which is confirmed by the relevant document. That is, the fact of registration of a vehicle in a foreign state frees a person from the obligation to make a pledge.

Thus, the most important distinction between the above-mentioned customs regimes is that transit allows motor transport to stay in the territory of Ukraine for up to 10 days, and the temporary importation regime - up to one year +60 days.

Facultative features of «Eurocars» are: 1) year of production of a vehicle; 2) the technical condition of the vehicle; 3 ) the purpose of import into the territory of Ukraine.

Year of production and technical condition are distinguished as an facultative because usually «Eurocars» are vehicles that were produced from 5-7 to 10-15 years ago. It is clear that a 15-year-old vehicle cannot be in good technical condition. Therefore, it would be possible to distinguish these features as the main ones. However, "Eurocars» can be an entirely new vehicle. That is why we are convinced that although these traits cannot be the main ones, they are also worthy of attention.

We are convinced that the purpose of import of such vehicles into the territory of Ukraine is: 1) personal use; or 2) resale on the territory of Ukraine; or 3 ) the use of another person; or 4) parse of the vehicle or spare parts. In our view, the above purposes are the most common, although we assume the presence of other purposes not listed in this paper.

The legal situation with «Eurocars», which is taking place in Ukraine today, can be viewed from two points of view. First of all, from the position of Ukrainian citizens and from the position of the state.

Undoubtedly, from the point of view of Ukrainian citizens, the purchase of such cars is profitable. Our compatriots have access to a cheap foreign car 
market. Instead of the product of the Ukrainian car industry - Daewoo Sens ( «younger brother» of Daewoo Lanos), whose price today varies within $7000 \$ 1$ - Ukrainians have the opportunity to buy for the same money, for example, Opel Astra 2011 2 , Audi A6 $2008^{3}$ or Skoda Octavia $2011^{4}$. Moreover, the cost of used cars abroad is much lower than in Ukraine.

However, from the point of view of the state, this situation is problematic. The lack of practically any legal relationship between the driver of «Eurocars» and his vehicle is the reason for the complication in the area of bringing the person to legal liability in the event of an accident: drivers can simply leave the place of the car accident, which will significantly burden the process of their search, because they have no legal connection with their car. In addition, there may be a situation in which the legitimate owner of the car will appear and will demand the return of his car. In this situation, the law is on the side of the legal owner. Thus, having purchased a vehicle worth several thousand euros in accordance with the model «money - keys, keys - money», a person can easily lose it on legitimate grounds. This predicted situation completely offset all the positive aspects of the purchase of cheap foreign cars, and the implementation of this process in compliance with the mentioned model.

Thus, taking into account all of the foregoing, we provide our own interpretation of the concept of «Eurocar», which means a new or used vehicle, registered in one of the countries of the European Union that was imported into the territory of Ukraine by a resident citizen or a non-resident citizen without paying the necessary customs duties for personal use, resale, transfer to a third party or for other purposes.

However, despite all the disadvantages of these cars, they are still popular. What are the reasons for this? Of course, this is their price. As is known from the economic theory, the price of any product is formed, in particular, taking into account obligatory payments to the budget. Thus, by imposing high taxes, the state forces manufacturers to add to the value of the product a certain amount, on the basis of which the value of the specific product is formed.

We will analyze the prices for individual models of the German automobile market as a country-producer and their value in Ukraine. For example, for today, the new Volkswagen Polo in Germany costs 12975 euros $^{5}$. At the same time, in Ukraine the same car is sold for UAH 452,525, which equals 13,692 $\operatorname{euros}^{6}$ (at the rate of $33.05 \mathrm{UAH}$ per 1 euro). Mercedes-Benz A-klass costs

${ }^{1}$ Data is obtained from the official website of the Zaporozhye Automobile Building Plant. For more information, see:

http://www.zaz.ua/models/sens-sd/price.html.

2 Data is obtained from the website of the portal auto.ria.com. For more information, see: https://auto.ria.com/autointer/auto-4-7605799.html.

${ }^{3}$ Data is obtained from the website of the portal auto.ria.com. For more information, see: https://auto.ria.com/autointer/auto-4-7602977.html.

${ }^{4}$ Data is obtained from the website of the portal auto.ria.com. For more information, see: https://auto.ria.com/autointer/auto-4-7608389.html.

${ }^{5}$ Data is obtained from the official website of the Volkswagen dealer in Germany. For more information, see:

https://www.volkswagen.de/de/models.html\#.

${ }^{6}$ Data is obtained from the official website of the Volkswagen dealer in Ukraine. For more information, see:

https://www.volkswagen.com/new-polo/new-polo. 
26,090 euros in Germany ${ }^{1}$, while in Ukraine, the price of this car starts at 29,062 euros ${ }^{2}$. The reason for this is the adoption on May 31, 2016 by the Verkhovna Rada of Ukraine the Law of Ukraine «On Amendments to Section XX of the" Transitional Provisions "of the Tax Code of Ukraine on Stimulating the Development of the Market of Used Vehicles", which amended the rates of excise tax on vehicles until 31 December 2018 [2]. However, according to par. 2 clause 15 of subsection 5 of section XX of the Tax Code of Ukraine (hereinafter - the TC of Ukraine) these rates do not apply if the car is imported by a person to the territory of Ukraine for own use or in favor of other persons [3]. This means that the car imports by citizens is at the rates provided in conformity with Article 215 of the TC of Ukraine.

Undeniably, today not every Ukrainian is able to pay 10-20 thousand euros per car. That is why it is possible to use "Eurocars», the price of which is several times lower than the market value of new cars from the car dealership. In many cases, drivers of such cars simply overdue the term of the vehicle's stay in Ukraine, thus violating the regulatory requirements of the Customs Code of Ukraine.

However, the competent authorities of the state also try to respond to these offenses. Thus, having analyzed the Unified State Register of Judicial Decisions (hereinafter - USRJD), we came to the conclusion that from January 1, 2018, 102 lawsuits against customs were filed to the courts of first instance to declare the actions of the subject of power unlawful and to repeal the decision on violation of customs rules. The percentage of appeals against decisions of courts of first instance is 50 percent. Appeals were filed both by individuals and representatives of customs ${ }^{3}$.

On the basis of the analysis of the USRJD, we received a list of some of the largest fines imposed on individuals for violation of customs rules in the form of delayed period of stay of a vehicle in transit or temporary importation on the territory of Ukraine: 1) $3651387 \mathrm{UAH}$ - imposed by Odessa customs office; the courts of the first and appellate courts refused to satisfy the claims for the annulment of the ruling [4; 5]; 2) $1785674 \mathrm{UAH}$ - imposed by the Chernihiv customs office; the courts of the first and appellate courts refused to satisfy the claims for the annulment of the ruling [6; 7]; 3) UAH 1,755,647 - imposed by the Kharkiv customs office; the court of first instance refused to satisfy the claims. The appeal is left without movement by the court [8;9]; 4) $1375590.39 \mathrm{UAH}$ - imposed by the Chernivtsi customs office; the court of first instance refused to satisfy the claims; there is no information on lodging an appeal [10].

There is no doubt that such fines cause considerable indignation among the drivers of «Eurocars», which is confirmed by quite frequent protest ${ }^{4}$.

${ }^{1}$ Data is obtained from the official website of the Mercedes-Benz dealer in Germany. For more information, see:

https://www.mercedes-benz.de/passengercars.html

${ }^{2}$ Data is obtained from the official website of the Mercedes-Benz dealer in Ukraine. For more information, see: http://www.mercedes-benz.kiev.ua/cars/models/a-class-new/hetchbek.html.

${ }^{3}$ Information is obtained on the basis of the own analysis of the Unified State Register of Court Decisions.

${ }^{4}$ For more information, see:

1) https://kiev.segodnya.ua/kother/centr-kieva-v-dymu-protestuyushchie-zazhgli-dymovyeshashki-1131650.html;

2) https:///24tv.ua/ru/vladelcy_evrobljah_zablokirovali_centr_kieva_foto_i_video_n997085 
In addition, the catalyst for such events was the adoption of a resolution of the Cabinet of Ministers of Ukraine «On the implementation of an experimental project to create conditions for impossibility of avoiding payment evasion from customs duties" dated June 20, 2018, No. 489. Thus, according to par 1 and 2, paragraph 2 of the resolution for the period from June 21, 2018 to December 31, 2018, the police: a) have the right to stay round the clock in the customs control zones at the points of entry through the state border and in other places of the customs territory of Ukraine in order to identify violations of customs rules; b) get access to the automated system of customs clearance «Inspector - 2006» [11]. Access to this program means that the police will be able to receive as soon as possible information on the date of importation of a vehicle in the territory of Ukraine and its term.

This raises the logical question of how this problem can be solved. There are currently several options available. The first option is the so-called «Moldovan variant», which helped the Republic of Moldova solve the problem of «Eurocars». Its essence was that for a certain period of up to 6 months, a 70 percent tax discount on vehicle registration was set. If the person did not register his car, she was obliged to pay a special fee for using the roads, which was equal to 1 euro per day. In case of violation of this provision, the car was crossed by police officers abroad at the expense of the driver. Thus, over half a year the state budget has been replenished at 21.6 million euros, which fully proves the effectiveness of the Moldovan variant [12; 13].

The essence of the second variant is quite simple and involves a significant reduction in excise tax rates. However, there are doubts as to whether or not government officials will agree with this proposal. On the one hand the direct consequence of a significant reduction in excise tax rates is the lack of a significant amount of cash in the budget. However, on the other hand, the presence of the problem in the unregulated state deprives the budget of any financial income from this sphere at all, which again emphasizes the importance of an early resolution of this issue.

The third option is a modernized «Moldovan variant»: temporarily, for a period of one year, to establish a significant tax deduction for customs clearance of vehicles. In the case of ignoring this provision, such vehicles should be confiscated.

There is also a fourth option. Its essence is not only to reduce the rates of excise tax, but also to change the system of its calculation. Today there are two drafts in the Parliament aimed at implementing the above-mentioned concept: the draft Law on amending the Tax Code of Ukraine regarding the taxation of motor vehicle excise tax No. 8487 [14] and the Draft Law on Amendments to the Tax Code of Ukraine and certain legislative acts of Ukraine concerning stimulation of development of the market of vehicles № 8487-1 [15]. Thus, the project 8487-1 proposes to reduce the rates of excise tax on vehicles on average by $2-5$ times $^{1}$. Project number 8487 proposes to replace the system of taxation of motor vehicles. Yes, it is suggested to calculate the rate by the formula:

Rate $=$ Base rate $\mathrm{x}$ Coefficient of engine $\mathrm{x}$ Coefficient of age, where: 1 ) base rate - Euro tax rate for 1 vehicle: 50 and 75 euros according to different types of engines; 2) coefficient of engine is a coefficient determined by dividing

${ }^{1}$ Data were obtained in accordance with the conclusion of the Committee of the Verkhovna Rada of Ukraine on Taxation and Customs Policy dated July 12, 2018. For more information, see: http://w1.c1.rada.gov.ua/pls/zweb2/webproc4_1?pf3511=64322. 
the cylinder volume of the internal combustion engine of the vehicle in cubic meter. cm per 1000 cubic centimeters; 3) coefficient of age is the coefficient equal to the number of full calendar years from the year following the year of manufacture of the corresponding vehicle to the year of determination of the tax rate.

For example, let us compare the amount of excise tax for a diesel engine with an engine volume of 2000 cubic centimeters, which has been used for more than five years, according to the existing and proposed systems. So, the current rate is set at 2,441 euro per 1 cubic centimeter of cylinder capacity of the engine ${ }^{1}$. That is, 2000 cubic centimeters $\times 2,441$ euro $=4,882$ euros. Thus, the amount of excise duty only amounts to almost five thousand euros. According to the system proposed in the draft, the calculation will be made according to the formula: $75 \times(2000: 1000) \times 5=750$ euros $^{2}$.

That is, the excise tax rate will be 750 euros, which is almost 6.5 times lower than the current one. In our opinion, the proposed model is rather progressive and one that will help solve the problem of «Eurocars». Today, the first steps of the state towards consensus can be seen: Draft No. 8487 was adopted in the first reading on July 13, 2018.

Conclusions. So, for today, our society is in a difficult situation. The problem encountered in this work is extremely relevant and sensitive to those Ukrainian citizens who use cars registered outside the territory of Ukraine.

The question of «Eurocars» is not only economic, but also political and social, because it is at the intersection of the interests of a large number of people with differentiated views on how to solve it. But the undisputed claim is that the lack of legal regulation of such legal relations is a negative phenomenon. in particular, for those who are forced to pay multimillion fines. That is why we are convinced that the quickest way to resolve the issue is to have positive effects.

\section{References}

1. Customs Code of Ukraine : Law of Ukraine, Dated March 13, 2012 No. 4495-VI. URL: http://zakon.rada.gov.ua/laws/show/4495-17 (date of access 21.09.2018).

2. On amendments to subsection 5 of section $\mathrm{XX}$ «Transitional provisions» of the Tax Code of Ukraine on stimulating the development of the market for used vehicles : Law of Ukraine, Dated May 31, 2016, No. 1389-VIII. URL: http://zakon.rada.gov.ua/laws/ show/1389-19 (date of access 21.09.2018).

3. The Tax Code of Ukraine : Law of Ukraine, Dated December 02, .2010 № 2755-VI. URL: http://zakon.rada.gov.ua/laws/show/2755-17 (date of access 21.09.2018).

4. Resolution of the Prymorskyi District Court of Odessa in case No. 522/19001/16-a, Dated November 03, 2017 : Uniform State Register of Court Decisions. URL: http:// reyestr.court.gov.ua/Review/70039535 (date of access 21.09.2018).

5. Resolution of the Odessa Administrative Court of Appeal on the case No. 522/19001/16-a, Dated February 28, 2018 : Uniform State Register of Court Decisions. URL: http:// reyestr.court.gov.ua/Review/72715309 (date of access 21.09.2018).

${ }^{1}$ Commodity position 8703329030 Ukrainian Classification of Goods for Foreign Economic Activity. The rate is received in accordance with clause 215.3.5-1 of paragraph 215.3 of Article 215 of the Tax Code of Ukraine.

275 is the base rate for a diesel engine type; (2000: 1000) is the definition of the engine coefficient, which is established by dividing the engine volume by 1000 cubic $\mathrm{cm}$; 5 is the number of full years of the vehicle. 
6. The decision of the Novoazovskyi District Court of Chernihiv in case No. 751/975/18, Dated June 5, 2018 : Uniform State Register of Court Decisions. URL: http://reyestr. court.gov.ua/Review/74528074 (date of access 21.09.2018).

7. Resolution of the Kyiv Appellate Administrative Court in case No. 751/975/18. Dated August 9, 2018 : Uniform State Register of Court Decisions. URL: http://reyestr.court. gov.ua/Review/75774617 (date of access 21.09.2018).

8. Resolution of the Kyiv District Court of Kharkiv in the case No. 640/6785/18, Dated July 16, 2018 : Uniform State Register of Court Decisions. URL: http://reyestr.court. gov.ua/Review/75315242 (date of access 21.09.2018).

9. The decision of the Kharkiv Administrative Court of Appeal in the Case No. 640/6785/18, Dated August 17, 2018 : Uniform State Register of Court Decisions. URL: http:// reyestr.court.gov.ua/Review/75957501 (date of access 21.09.2018).

10. Decision of Pershotravnevyi District Court of Chernivtsi in case No. $725 / 3783 / 18$, Dated August 21, 2018 : Unified state register of court decisions. URL: http://reyestr. court.gov.ua/Review/76020339 (date of access 21.09.2018).

11. On the Implementation of an Experimental Project to Create Conditions for Impossibility of Avoiding Payment Evasion from Customs Duties : Resolution of the Cabinet of Ministers of Ukraine, Dated June 20, 2018, No. 479. URL: http://zakon.rada.gov.ua/ laws/show/479-2018-\% D0\% BF (date of access 21.09.2018).

12. «Moldavian Scenario» for «Eurocars»: How Ukraine's Neighbors Fought Against Unauthorized Cars : Segodnya.ua, 2018. URL: https://www.segodnya.ua/ economics/avto/moldavskiy-scenariy-dlya-evroblyah-kak-sosedi-ukrainy-borolis-snerastamozhennymi-avto-1123829.html (date of access 21.09.2018).

13. "Customs Clearance of Cars According to the Moldavian Scenario»: What Is It?: Auto. ria.com, 2018. URL: https://auto.ria.com/news/ autolaw/236755/ rastamozhka-avtopo-moldavskomu-sczenariyu-chto-eto-takoe.html (date of access 21.09.2018).

14. On Amendments to the Tax Code of Ukraine Regarding the Taxation of Excise Tax on Motor Vehicles : Draft Law of Ukraine, Dated June 15, 2018, No. 8487. URL: http:// w1.c1rada.gov.ua/pls/zweb2/webproc4_1?pf3511=64235 (date of access 21.09.2018).

15. On Amendments to the Tax Code of Ukraine and Certain Legislative Acts of Ukraine on Stimulating the Development of the Market of Vehicles : Draft Law of Ukraine, Dated June 27, 2018, No. 8487-1. URL: http://w1.c1.rada.gov.ua/pls/zweb2/ webproc4_1?pf3511=64322 (date of access 21.09.2018).

16. On Certain Issues of Import into the Customs Territory of Ukraine and Registration of Vehicles: Law of Ukraine dated July 6, 2005 No. 2739-IV. URL: http://zakon.rada.gov. ua/laws/show/2739-15 (date of access 15.09.2018).

17. Code of Administrative Offenses of Ukraine (Articles 1 - 212-20): Law of the USSR dated December 07, 1984, No. 8073-X. URL: http://zakon.rada.gov.ua/laws/show/80731-10 (date of access 15.09.2018). 


\section{Є. О. Каташинський}

Одеський національний університет імені I. І. Мечникова, кафедра адміністративного та господарського права

Французький бульвар, 24/26, Одеса, 65058, Україна

\section{ОКРЕМІ АСПЕКТИ ПРАВОВОГО РЕГУЛЮВАННЯ ВИКОРИСТАННЯ ТРАНСПОРТНИХ ЗАСОБІВ, ЗАРЕЕСТРОВАНИХ В КРАЇНАХ СВРОПЕЙСЬКОГО СОЮЗУ ( СВРОБЛЯХ»)}

\section{Резюме}

У статті розглядаються питання правового регулювання використання автомобілів, зареєстрованих на території країн Європейського Союзу та ввезених на територію України («євроблях»). Автором надається власне тлумачення терміну «євробляха», а також виокремлюються його ознаки. В роботі аналізуються шляхи вирішення проблеми використання таких автомобілів.

Ключові слова: автомобілі, зареєстровані за межами території України, євробляхи, митні правила.

\section{Е. А. Каташинский}

Одесский национальный университет имени И. И. Мечникова, кафедра административного и хозяйственного права

Французский бульвар, 24/26, Одесса, 65058, Украина

\section{ОТДЕЛЬНЫЕ АСПЕКТЫ ПРАВОВОГО РЕГУЛИРОВАНИЯ ИСПОЛЬЗОВАНИЯ ТРАНСПОРТНЫХ СРЕДСТВ, ЗАРЕГИСТРИРОВАННЫХ В СТРАНАХ ЕВРОПЕЙСКОГО СОЮЗА ( ЕВРОБЛЯХ»)}

\section{Резюме}

В статье рассматриваются вопросы правового регулирования использования автомобилей, зарегистрированных на территории стран Европейского Союза и ввезенных на территорию Украины («евроблях»). Автор предлагает собственное толкование термина «евробляха», а также выделяет его признаки. В работе анализируются пути решения проблемы использования таких автомобилей.

Ключевые слова: автомобили, зарегистрированные за пределами территории Украины, евробляхи, таможенные правила. 